\title{
Willingness to Pay for Halal Transportation Cost: The Moderating Effect of Knowledge on the Theory of Planned Behavior
}

\author{
Hafaz N.A, Jagan Jeevan, Nurul Haqimin Mohd Salleh, Taylor Tae Hwee Lee, Siti Marsila Mhd \\ Ruslan
}

\begin{abstract}
Halal transportation services is one of the crucial components of producing Halal products. Since Halal is unique and involves elaborate regulations and executions, therefore it requires huge investment. Like any other supply chain, the transportation cost will be transferred to the end users, normally the customers, thus increasing the price of final products. It is notably common to find studies done on Muslim customers and their preference on Halal products, however, studies on Muslims preferences towards Halal transportation could still be considered as novel. By adopting the Theory of Planned Behavior and religiosity; and by taking into account the moderating effect of knowledge, this study aims to identify the factors that lead to the customers' willingness to pay for the Halal transportation cost. Using a purposive sampling method, the data was collected among Muslim consumers in a prominent shopping complex in Malaysia and was analyzed using Smart Partial Least Squares (PLS). Based on the finding, it is shown that the attitude and perceived behavioral control gave a positive relationship with the willingness to pay for Halal transportation. Meanwhile, subjective norm and religiosity were on the opposite as there were both hold an insignificant effect towards the willingness to pay for the Halal transportation. Knowledge has moderated the relationship between attitude and willingness to pay for Halal transportation, but not for the relationship between subjective norm and perceived behavioral control. It is expected that this study could provide a better understanding of Muslim consumers' behavior on purchasing for Halal transportation, as well as other Halal supply chain activities.
\end{abstract}

Index Terms: Theory of Planned Behavior; Willingness to pay; Halal transportation Cost; moderating effect.

\section{INTRODUCTION}

Halal is an Arabic word which means "allowed to consume". It has slowly become well known due to the emerging number of Muslim population all around the world. The uniqueness of Halal products lies under a specific Islamic

Revised Manuscript Received on September 22, 2019.

Hafaz N.A, Maritime Management, School of Business Maritime and Management, Universiti Malaysia Terengganu, Kuala Nerus, Terengganu, 21030, Malaysia. hafaz.ngah@umt.edu.my

Jagan Jeevan, Maritime Management, School of Business Maritime and Management, Universiti Malaysia Terengganu, Kuala Nerus, Terengganu, 21030, Malaysia

Nurul Haqimin Mohd Salleh, Maritime Management, School of Business Maritime and Management, Universiti Malaysia Terengganu, Kuala Nerus, Terengganu, 21030, Malaysia

Taylor Tae Hwee Lee, Department of Distribution, Gyeongnam National University of Science and Technology, Jinju, South Korea

Marsila Mhd Ruslan, Maritime Management, School of Business Maritime and Management, Universiti Malaysia Terengganu, Kuala Nerus, Terengganu, 21030, Malaysia guideline which emphasizes the purity and hygiene to maintain, preserve and sustain the wellbeing of humankind. Nowadays, Halal is not only restricted to the selection of food, but also in many other areas such as pharmaceuticals, cosmetics, banking as well as logistic services, such as transportation and warehousing activities. A Halal certified product must not only pass the inspection in the manufacturing practice but also in the whole supply chain to ensure that it completely complies with the whole Halal requirement.

Halal products are guaranteed Halal to be consumed if they are handled based on Shariah requirements in the whole chain of practices (Hafaz, Zainuddin, \& Thurasamy, 2014b) and Halal transportation is one of the important issues that need to be addressed in order to achieve a complete Halal requirement (Hafaz \& Thurasamy, 2018). Therefore, by looking at the demand from the Muslim community, logistic providers are now slowly begin to offer Halal transportation services as part of the initiatives in establishing Halal supply chain to the mass (Bahrudin, Illyas, \& Desa, 2011; Hafaz, Zainuddin, \& Thurasamy, 2017). As an attempt to attract Muslim consumers, Halal manufacturers have started incorporating Halal transportation services into their businesses (Ali, Tan, Makhbul, \& Hafaz, 2016; Hafaz, Zainuddin, \& Thurasamy, 2014a). This, among others, could be seen as a wise step since the majority of Halal manufacturers are non-Muslims, therefore incorporating Halal transportation could further strengthen the customers' trust for a better Halal supply chain (Tieman \& Ghazali, 2013; Hafaz et al., 2014b),

Previous studies had shown that customers opt for Halal products at the time of purchase (Bahrudin et al., 2011; Hafaz, Zainuddin, \& Thurasamy, 2015; Hasan Bukhari et al., 2019). Nevertheless, it is uncertain to define whether they are willing to pay for Halal transportation charges. According to Kamaruddin, Iberahim, and Shabudin, (2018) consumers are mostly indecisive to pay for Halal services, however acknowledging the quality of Halal products that they might get, it has convinced some of them to pay for Halal transportation. Transforming from conventional to halal logistics is costly due to specific quality requirements, namely MS 2400-1:2010. While the processes in obtaining the Halal status seem to be tedious, nonetheless it is crucial to ensure that the industry remains competitive (Khan, 
Najmi, Ahmed, \& Aman, 2019). On the other hand, it is shown in the previous studies that customers are looking forward to the green practice, however, are reluctant to pay for the implementation purposes. (Manaktola \& Jauhari, 2007; Choi \& Parsa, 2007).

As mentioned above, this study intends to fill the gap by identifying the factors influencing Muslim consumers' willingness to pay for Halal transportation cost. Recognizing the factors that relate to the willingness to pay for Halal transportation cost is important not only for Halal transportation providers but also crucial as part of the process for Halal manufacturing practice. Tieman (2011) and Syazwan, Talib, Rubin, and Khor (2013) further cemented this statement by emphasizing the need to provide a clearer picture of this issue. Many studies have been done on Halal such as Halal adoption (Hafaz \& Thurasamy, 2018; Hafaz, Zainuddin, \& Thurasamy, 2014c) intention to purchase Halal products (Lada, Harvey Tanakinjal, \& Amin, 2009); Halal logistics (Syazwan et al., 2013; Omar \& Jaafar, 2011); as well as principle in Halal supply chains (Tieman, 2013). Nevertheless, the issue on the willingness to pay for Halal transportation cost still remains scarce. One study was done by Kamaruddin et al., (2018) however had raised up the connotation on this matter, but with a different framework.

Incorporating the Theory of Planned Behavior that linked with religiosity, this study intends to extract out the factors that influence the willingness to pay for Halal transportation cost among Muslims in Malaysia. In order to augment the findings, knowledge was used as a moderating factor in the research framework. Finally, it is expected that the outcome of this study could serve as a yardstick to redefine the Halal practice performance, particularly to Halal transportation providers and Halal manufacturers in the future (Hafiz, Jie, \& Chan, 2018).

\section{LITERATURE REVIEW}

This section will start with the literature on the willingness to pay for the Halal transportation cost, and continue with independent variables of the studies with a complete hypothesis, and ended with the development of the research framework of the study.

\section{A. Halal transportation}

Halal transportation is a part of a service in halal supply chain activities. Halal transportation is a phase that, all halal products must pass through before getting at the point of sale. There are two types of cost could be paid by customers which are primary; inbound to the manufacturers, and outbound to distribution centers, or point of sale, and secondary cost such as other operating costs (Kamaruddin, Iberahim, \& Shabudin, 2012). Incorporating Halal practices in conventional logistics increases the responsibility of logistics service providers as products with Halal attributes requires dedicated equipment (Haleem et al., 2018). Since the transportation providers also require huge investment before being certified as Halal transporter, hence the cost of obtaining the Halal certification which includes of a new process, tools, and human resource; as a service provider, the cost will be transferred back to the consumers.

Halal transporter will handle Halal products accordingly to preserve the Halal quality of the merchandise. Halal products should be segregated at all points of activities with non-Halal products, or any contaminated products by all means. Since clear guidance between Halal and Haram, as mentioned by Hadiths and Quran, separating these two categories are required to maintain the Halal quality. Once Halal products become Haram (illegal to use) due to neglect in certain activities, using Halal transportation services will not turn Haram to be a Halal product. (Tieman, 2011) .

\section{B. Willingness to pay for the Halal transportation cost}

Willingness to pay has been defined as the highest amount than consumer willing to sacrifice in order to get the services. According to Jedidi and Zhang (2003) willingness to pay has been delineated as an economic term, price associated, or the highest amount of consumer willing to compensate for certain goods or services. The study defines the willingness to pay as the maximum amount of monetary value that consumer willing to be exchanged in order to get the required services or goods. Customers may look for the desired services, but not all of them surely willing to pay for the services.

According to Rivis, Sheeran, and Armitage (2006) noted that behavioral of willingness as a realization that one would be willing to enlist in the behavior under circumstances. Kamaruddin et al., (2018) advised that due to preserving the Halal quality, Muslim consumer apparently willing to compensate for the Halal logistic cost.

From the researchers' point of view, Willingness to pay is believed to be a better predictor than the intention to buy since not all intention will translate into actual purchasing. Even willingness will not translate to the actual buying, but willingness will show that, in a certain situation, customers are going to engage in the services even they don't have any intention to pay the price of the goods or services. Contradict to intention, which the measurements are more business organization on planning behavior, however, willingness to work on certain conduct does not involve planning or consideration of behavior's likely consequences. It can consider that willingness to certain behavior can provide a better variance compare to intention to involve certain behavior.

\section{Theory of planned behavior}

Theory of planned behavior (Ajzen, 1991) can be considered as the most frequently used theory to explain consumer behavior at the individual level. Most of the study used this hypothesis to predict the individual's intention on certain behavior such as the intention to adopt a novel technology or intention to buy merchandise. The versatility of this hard theory which consists of attitude, subjective norms and perceived behavioral control make this theory applicable in diverse fields of work. The attitude has been defined as individual's overall judgment and assessment of behavior and Subjective norms as a societal pressure to perform or not to execute the behavior or not to execute the object behavior (Ajzen, 1991; Hafaz, Rahimi, \& Norzalita, 2018). Meanwhile perceived behavioral control as the belief that an important person or group of people will approve and defend a peculiar behavior (Ajzen, 1991). Even 
the theory is fixed with those three variables, Ajzen (1991) suggesting that other variables could be tallied in the study to increase the explained variance of the endogenous variable.

Thither are many studies have applied the Theory of Planned Behavior to explain the willingness to pay or certain behavior in several disciplines of studies. Firstly, (Spash et al., 2009) revealed that, in the biodiversity study, all the variables in this theory have a positive relationship with the willingness to pay. On the environmental study, (López-Mosquera, García, \& Barrena, 2014) found that the variables in the theory also have a positive relationship with the willingness to pay. On the other hand, on a green behavior study, (Yadav \& Pathak, 2017) affirmed that the attitude, subjective norms and perceived behavioral control to have a positive relationship with the willingness to pay. The attitude was found to possess a positive relationship with the willingness to pay (Meleddu \& Pulina, 2016; (Sánchez, López-Mosquera, Lera-López, \& Faulin, 2018). Hence, the study follows the literature to develop the hypothesis of the study;

H1: Attitude has a positive relationship with the willingness to pay for the Halal transportation cost.

H2: Subjective norms have a positive relationship with the willingness to pay for the Halal transportation cost.

H3: Perceived behavioral control has a positive relationship with the willingness to pay for the Halal transportation cost.

\section{Religiosity}

The limitation of Theory of Planned Behavior in explaining the variance which leads to researchers to add a new dimension with the Theory of Planned Behavior itself (Tommasetti, Singer, Troisi, \& Maione, 2018). Furthermore, Ajzen (1991) purported to add some other variable which might provide a fuller explanation of the intended behavior of the study. Sanchez et al., (2018) also claimed it was necessary to add a new dimension while using Theory of Planned Behavior as a foundation in the theoretical framework. Furthermore, Even (Weaver \& Agle, 2002) confirmed that religiosity has a strong effect on consumers' behavior, however, due the varies in strength on their religiosity from one person to another, the absolute role of religiosity on food choices still unclear (Bonne \& Verbeke, 2008). Since Halal is part of the Muslims' obligation, the study decides to add religiosity as a new variable to form the research framework.

Islamic values will provide a clear path on what must, encourage, allow and what their follower can't perform on their daily lives. (Kotler \& Zeithaml, 2000) mentioned that religiosity will affect the Muslim consumers' decision, but unsure how much it will influence the Muslims. Furthermore, Islam is not only as a matter of religion but for the Muslims, Islam is the way of life. Religiosity is a person's belief on the absolute inherent truth and qualities and submission to a religion's scriptures and teaching. In this study, scripture is referring to the Quran, and teaching is whatever taught by Prophet Muhammad SAW. Worthington et al., (2003) proposed that, religiosity is the degree of a person obliged and practice the religious value in their daily lives. Essentially, whole faiths have their messenger and their holy scriptures. Hence, the study defines religiosity as the level of ones to

adhere to what has been taught by their messenger and what has been stated by its holy scripture.

Alam, Mohd, and Hisham (2011) suggested that religiosity is crucial in shaping individual behavior and will behave as guidance on their future behavior (Pettinger, Holdsworth, \& Gerber, 2004). On the other hand, higher submission to his religion, teaching, the internal state of the individual will form a consciousness of certain behavior, (Choi, 2010) especially related to the rules stated in his religion. The study on willingness to donate organ found that religiosity is a significant factor (Kim \& Choi, 2016). Religiosity has a positive relationship with the willingness to open Islamic gold account, (Amin, 2016) and (Ahmed, Najmi, Faizan, \& Ahmed, 2018) found that religiosity positively related to the willingness to pay for Halal products. Hence; hypotheses postulated as below;

H4: Religiosity has a positive relationship with the willingness to pay for Halal transportation.

\section{E. Knowledge as a moderating factor.}

The moderating variable has become more popular in social science and business studies across the globe. It shows model complexity and maturity which offer a better perspective regarding the criterion variable of the study (Aguinis, Boik, \& Pierce, 2001). According to Baron and Kenny (1986), the moderator variable could introduce due to weak or inconsistent in the literature regarding the relationship between the predictor and the criterion variable. The study also found inconsistency in variables in the theory of planned behavior with the willingness behavior in a few different studies. Ahmed et al., (2018) found that attitude was an insignificant factor in the relationship towards a willingness to pay for Halal products. Sanchez et al., (2018) found that subjective norm and perceived behavioral control were not significant towards a willingness to pay to reduce noise pollution. Hence, the study has found a valid cause to introduce moderator in the research framework.

The variables representing planned behavior theory are referred to the cognitive determinants that would involve the person's behavior (Rivis et al., 2006). Since it is linked to cognitive characteristic, the construct that could be a moderator for the study also must be linked up to the cognitive component. Therefore, this field would try to use knowledge as a moderator for the study since knowledge also part of the cognitive ingredients. Generally, knowledge refers to the facts, feelings or experiences known by a person or a group of people; it can as well be defined as awareness, consciousness, or familiarity gained by experience or learning. To be specific, knowledge means the expertise and skills acquired by a person or a group of people through a theoretical or practical understanding of a subject (Ahmat, N.C., Radzi, S.M., Zahari, M.S.M., Muhammad, R., aziz, A.A. and Ahmad, 2011). Higher knowledge could provide positive results for the relationship between attitude, subjective norms and perceived behavioral control towards a willingness to pay for Halal transportation cost. Hence, hypotheses are formulated as follows: 
H5: The positive relationship between attitude and willingness to pay for the halal transportation cost will be stronger when the knowledge is high.

H6: The positive relationship between subjective norms and willingness to pay for the halal transportation cost will be stronger when the knowledge is high.

H7: The positive relationship between perceived behavioral control and willingness to pay for the halal transportation cost will be stronger when the knowledge is high.

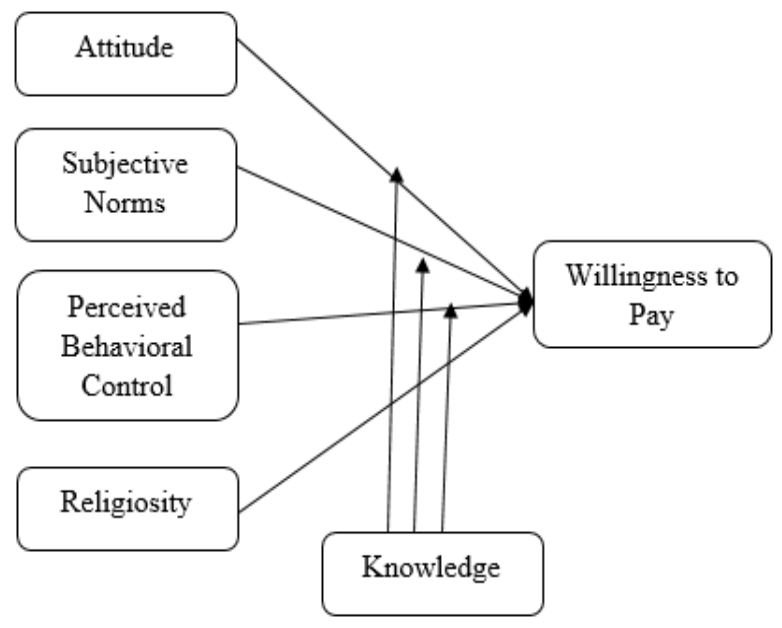

Fig 1: Theoretical Framework

\section{Methodology/Materials}

To test the hypothesis in the research framework, a quantitative approach using self-administered questionnaire was adopted. Since the unit of analysis of this study is at the individual level, which conduces to the unavailability of sampling frames, non-probability with purposive sampling method was used. There are two sections in the questionnaire. Part A, regarding their profile, such as gender, monthly income, highest qualification, and their working status, and part B consist of exogenous and endogenous variables of the study. To ensure the data are represented people in Malaysia, the respondents need to declare the state of origin, which will be transformed into the region, in the data analysis section. There are four regions which are North (Johor, Melaka), Centre (Negeri Sembilan, Selangor, Kuala Lumpur), East (Terengganu, Kelantan, and Pahang) and North (Perak, Penang, Kedah, and Perlis). Data were gathered at a major shopping complex in Terengganu, Kelantan, and Pahang. Respondents of the study are the Muslims who are already employed to enhance the validation of the decision on the willingness to pay for the Halal transportation cost. Realizing the importance of the quality of the data, voluntariness is crucial for the study. Hence, respondents were asked about the willingness to participate in the study. The questionnaire only will be given, if they agree to be the respondents of the survey.

More than 250 potential respondents were approaching, only 179 of them were willing to be involved in the study. Since they are voluntary and willing, in that respect is no missing values among the data, and all of the data are safe enough to be analyzed to answer the research questions of the subject area. As proposed by (Hair, Hollingsworth, Randolph,
\& Chong, 2017), the sample size should be determined according to the power of analysis, which based on the number of predictors. (Green, 1991) developed a table to determine the minimum sample size based on the power of analysis. Based on the table, with eight predictors, $80 \%$ power, medium effect size and significant at 5\%, the minimum sample size is 108 . Hence, with 179 respondents of the study, the number of the respondent is not an issue in the study.

All the items to measure the constructs were adopted and adapted from previous studies. The item for attitude, subjective norms, perceived behavioral control from (Venkatesh, Brown, \& Hoehle, 2012), religiosity and knowledge (Rahman, Asrarhaghighi, \& Rahman, 2015), and willingness to pay (Fathi, Zailani, Iranmanesh, \& Kanapathy, 2016).

\section{RESULTS AND FINDINGS}

Majority of the respondents are female, age between 23-30 years old, having a diploma as their highest qualification and range of monthly income between RM 1501-RM 3000. Since data were collected in the east region (Terengganu, Kelantan, and Pahang), hence the majority of the respondents (30\%) were from this area. The data of the study are represented Malaysia since it involved respondents from all around Malaysia (South, North, East, and Centre). Table 1 illustrates the demographic profile of the respondents

\begin{tabular}{llll}
\multicolumn{4}{c}{ TABLE 1: RESPONDENT PROFILE } \\
\hline \multirow{2}{*}{ Construct } & \multicolumn{2}{l}{ Frequenc } & $\%$ \\
\hline Gender & Male & 81 & 0.45 \\
Age & Female & 98 & 0.55 \\
& $18-22$ & 12 & 0.07 \\
& $23-30$ & 83 & 0.46 \\
& $31-40$ & 47 & 0.26 \\
Qualification & 41-50 & 30 & 0.17 \\
& More than 50 & 7 & 0.04 \\
& Secondary School & 25 & 0.14 \\
Region & Diploma & 65 & 0.36 \\
& Degree & 76 & 0.43 \\
& Post Graduate & 11 & 0.07 \\
& South & 43 & 0.24 \\
Income & North & 48 & 0.26 \\
& East & 53 & 0.3 \\
& Centre & 35 & 0.2 \\
& less than 1500 & 22 & 0.12 \\
& 1501-3000 & 72 & 0.40 \\
& 3001-4500 & 50 & 0.28 \\
& & 179 & 100 \\
\hline \multirow{4}{*}{ Total } & & &
\end{tabular}

Smart Partial Least Squares (PLS) is a variance based software which suitable for the study which focused on the prediction between variables in the research model. Even Smart PLS is using a structural equation modeling approach, it still based on the regression analysis. Hence the normality test is still required to ensure that the data is highly not 
normal. Based on (Kline, 2011), the data assume as normal if the sickness is \pm 1 , and Kurtosis is \pm 7 . Hair et al., (2017) proposed to assess multivariate skewness and Kurtosis using the link in the web power which available through online. Multivariate skewness and kurtosis for the study at the link https://webpower.psychstat.org/models/kurtosis/results.php? url=64e873d898e8f07287f896983e3d643b shows that the Mardia's multivariate skewness $(\beta=11.850, \mathrm{p}<0.01)$ and Mardia's multivariate kurtosis $(\beta=71.717, p<0.01)$. Hence, the data was slightly not normal and it is appropriate to apply the Smart PLS software in this study.

Next, is to test the common method variance (CMV), which claimed that it should be a problematic issue for the study if the data were collected from the single source (Podsakoff, MacKenzie, \& Podsakoff, 2012). To overcome the CMV, the study applied both methods; which are the procedural and statistical method. For procedural, two scales were used to reduce method biases caused by commonalities in scale endpoints (Podsakoff, MacKenzie, Lee, \& Podsakoff, 2003). The exogenous variables were measured by 5 point scale, meanwhile the endogenous with 7 point scale. For the statistical method, Harman single factor test (HSFT) was applied. The CMV is a serious issue for the study is the first factor explained more $40 \%$ of the variance of the study (Babin, Griffin, \& Hair, 2016). The un-rotated factor analysis revealed that the first factor only carried $30.2 \%$ of the total variance explained, thus, confirming that the CMV is not a serious threat to the study.

The study applied Smart Partial Least Squares (PLS) version 3.2.8 (Ringle, Wende, \& Becker, 2015) to test the hypothesis of the study. Smart PLS is a family of structural equation modeling (SEM) software, which is a variance based analysis that suitable for predictive purposes (Urbach \& Ahlemann, 2010). Compared with the variance based software, which is not suited for the study due to the subject does not have an intention to reproduce the covariance matrix to achieve a model fit (Hair et al., 2017). There are two steps of analysis should be run which are the (F. Ali, Rasoolimanesh, Sarstedt, Ringle, \& Ryu, 2018)measurement model, and the structural model.

\section{A. Measurement model}

The measurement model is to establish the validities of the relationship between items and the constructs in the research framework. There are two validities should be met in the measurement model; convergent validity and discriminant validity. Convergent validity to ensure that the multiple items used to measure the construct really measure that construct. According to Hair et al., (2013), convergent validity can be achieved if the loading is $\geq 0.5$, the average variance explained (AVE) is $\geq 0.5$ and the Composite Reliability (CR) is $\geq 0.7$. Based on table 2, all the values for loading, AVE, and CR surpass the minimum threshold values set by (Hair, Ringle, \& Sarstedt, 2013). Loadings are in the range of (0.674-0.949), AVE in the range of (0.539-0.864) and the CR is in the range of (0.853-0.950), thus, it can be confirmed that the convergent validity has been established for the study. TABLE 2: CONVERGENT VALIDITY

\begin{tabular}{|c|c|c|c|c|}
\hline $\begin{array}{l}\text { Constr } \\
\text { uct }\end{array}$ & Item & $\begin{array}{l}\text { Load } \\
\text { ing }\end{array}$ & CR & $\begin{array}{l}\text { AV } \\
\text { E }\end{array}$ \\
\hline Attitud & Paying for the Halal transportation & 0.91 & 0.94 & 0.8 \\
\hline e & cost is a good idea & 4 & & 08 \\
\hline
\end{tabular}
Paying for the Halal transportation 0.89
cost is a wise idea
0
I like the idea of paying for the Halal 0.90
transportation cost
6
Paying for the Halal transportation 0.88 cost is pleasant
6

Knowl I understand Islamic laws of Halal $0.82 \quad 0.87 \quad 0.5$

$\begin{array}{lllll}\text { edge } & \text { and haram in Transportation } & 8 & 1 & 76\end{array}$

I feel that I have sufficient $\quad 0.78$

knowledge of Halal transportation 3

I have enough knowledge to

differentiate between Halal and

0.69

Haram

2

I know about current issues

0.67

regarding Halal transportation 4

I know the difference between Halal 0.80

product and Halal transportation 5

service

5

Perceiv I have control to pay for the halal $0.84 \quad 0.890 .6$

ed transportation cost

$\begin{array}{lll}0 & 9 & 90\end{array}$

Behavi I have the resources necessary to 0.85

Control pay for the halal transportation cost 3

I have the knowledge necessary to 0.83

pay for the halal transportation cost 1

Given the resources, opportunities,

and knowledge it would be easy for 0.79

me to pay for the Halal

6

transportation cost

Religio I am happily and willingly pay my $\quad 0.81 \quad 0.85 \quad 0.5$

$\begin{array}{lllll}\text { sity zakat on time } & 5 & 3 & 39\end{array}$

I enjoy spending time with others of 0.73

my religious affiliation 2

I often participate in religious talk at 0.77

mosque

9

I often read religious books and $\quad 0.66$

magazines

0

I often watch religious programs on 0.67

TV.

4

Subject People who influence my behavior

ive think that I should pay for the halal

Norm transportation cost

$\begin{array}{lll}0.86 & 0.87 & 0.7\end{array}$

People who are important to me

think that I should pay for the halal 0.90

transportation cost

Willing I'm willing to pay for Halal

ness To transportation service even though $\begin{array}{llll}0.92 & 0.95 & 0.8\end{array}$

Pay choices are limited

I'm willing to pay for Halal

transportation because the benefits

outweigh the cost

Paying for Halal transportation

service is the right thing to do even

if they cost more

$\begin{array}{lll}6 & 9 & 85\end{array}$

5

$\begin{array}{lll}1 & 0 & 64\end{array}$

0.94

9

8

Once the convergent validity has been established, next is discriminant validity, which to ensure that the construct is truly distinct from the other construct and also measuring on how much indicator represent only on a single construct (Gholami, Sulaiman, Ramayah, \& Molla, 2013). Accurate assessment on discriminant validity is crucial to confirm that the constructs are

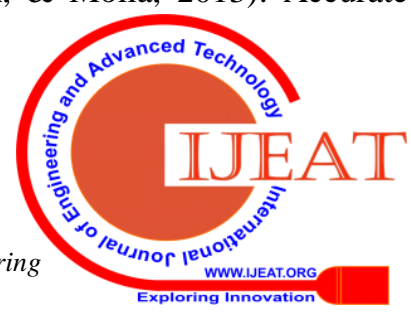


statistically unique and differ from other constructs (Hair et al,. 2019) As proposed by (Henseler, Ringle, \& Sarstedt, 2014), at this stage, the study will report it using the Heterotrait-Monotrait (HTMT) ratio. If the HTMT value is greater than 0.85 (Franke \& Sarstedt, 2018), thus indicating a serious issue in discriminant validity. Table 3 shows that discriminant validity has been established for the study due to all values for the HTMT were lower than the most conservative value set by (Franke \& Sarstedt, 2018). TABLE 3: DisCRIMINANT VALIDITY: HTMT

\begin{tabular}{|c|c|c|c|c|c|}
\hline Construc & \multirow{2}{*}{\multicolumn{2}{|c|}{ Att $\begin{array}{c}\text { Knowle } \\
\text { dge }\end{array}$}} & $\mathrm{Pb}$ & Religios & \multirow{2}{*}{$\mathrm{SN}_{\mathrm{TP}}{ }^{\mathrm{W}}$} \\
\hline $\mathrm{t}$ & & & c & ty & \\
\hline Att & & & & & \\
\hline Knowle & 0.2 & & & & \\
\hline dge & 97 & & & & \\
\hline $\mathrm{Pbc}$ & $23^{0.6}$ & 0.234 & & & \\
\hline Religiosi & 0.4 & 0250 & 0.4 & & \\
\hline ty & 34 & 0.259 & 51 & & \\
\hline SN & $54^{0.5}$ & 0.159 & $23^{0.5}$ & 0.421 & \\
\hline WTP & $42^{0.5}$ & 0.353 & $34^{0.5}$ & 0.356 & $34^{0.4}$ \\
\hline
\end{tabular}

\section{B. Structural model}

Before continuing to the hypothesis testing, it is essential to confirm that the lateral collinearity is not a problematic issue in the structural model. According to (Diamantopoulos \& Siguaw, 2006), the variance inflation factor (VIF) which measure the collinearity must be lower than 3.3. Table 4 indicates that all the VIF values are lower than the threshold value set by Diamantopoulos \& Siguaw, (2006), thus confirming the culinary is not a problem for the study. For the hypothesis testing, using the bootstrapping technique with a re-sampling of 500 as suggested by (Hair et al., 2017), the decision to accept the hypothesis is based on t-value, $p$-value and also confidence interval bias corrected. From the analysis, from seven hypotheses developed, only three hypotheses were supported. The study found that attitude was positively related to willingness to pay $(B=0.236, t=2.846$ : $\mathrm{LL}=0.101, \mathrm{UL}=0.405, \mathrm{P}<0.01)$ and perceived behavioral control $(\beta=0.229, \mathrm{t}=1.895$ : $\mathrm{LL}=0.039, \mathrm{UL}=0.374, \mathrm{P}<$ $0.05)$. Hence $\mathrm{H} 1$ and $\mathrm{H} 3$ were supported. Meanwhile the study found that subjective norm $(\beta=0.112, \mathrm{t}=1.499$ : $\mathrm{LL}=$ $-0.020, \mathrm{UL}=0.214, \mathrm{P}>0.05)$ and religiosity $(\beta=0.089, \mathrm{t}=$ 1.417: $\mathrm{LL}=-0.024, \mathrm{UL}=0.219, \mathrm{P}>0.05)$. Hence, $\mathrm{H} 2$ and $\mathrm{H} 4$ were unsupported.

Table 5 shows the assessment of coefficient of determination (R2), the effect size (f2) as well as the predictive relevance (Q2) of exogenous variables on endogenous variables of willingness to pay. Based on the table the R2 of 0.292 indicated that attitude, subjective norm and religiosity explain $29.2 \%$ of the overall variance of willingness to pay for the Halal transportation cost. For the predictive relevance, using the blindfolding procedure, according to (Hair et al., 2013), the Q2, which higher than 0 , indicates that the model has a predictive relevance. On the effect size, according to Cohen, (1992), for effect size; $0.35,015$, and 0.02 consider as large, medium and small effect size respectively. Hence, both variable, attitude and perceived behavioral control have a small effect size on the willingness to pay for the Halal transportation cost. TABLE 4: STRUCTURAL MODEL/HyPOTHESIS TESTING

\begin{tabular}{lllllllll}
\hline $\begin{array}{l}\text { H'the } \\
\text { sis }\end{array}$ & R'ship & $\begin{array}{l}\text { Bet } \\
\text { a }\end{array}$ & Se & CI & $\begin{array}{l}\text { T } \\
\text { val } \\
\text { ue }\end{array}$ & $\begin{array}{l}\text { Valu } \\
\text { es }\end{array}$ & $\begin{array}{l}\text { Decision } \\
\text { F }\end{array}$ \\
\hline H1 & Att $\rightarrow$ & 0.2 & 0.0 & $0.101 ; 0.4$ & 3.0 & 0.00 & Supporte & 1.7 \\
& WTP & 63 & 87 & 05 & 16 & 1 & d & 07 \\
H2 & SN -> & 0.1 & 0.0 & $(-0.020 ; 0$ & 1.5 & 0.06 & Unsuppo & 1.3 \\
& WTP & 07 & 69 & $.214)$ & 54 & 0 & rted & 31 \\
H3 & $\begin{array}{l}\text { Pbc } \\
\text {->WTP }\end{array}$ & 9.1 & 0.1 & $0.039 ; 0.3$ & 1.9 & 0.02 & Supporte & 1.5 \\
& $\begin{array}{l}\text { Religio } \\
\text { H4 }\end{array}$ & 0.1 & 0.0 & 74 & 45 & 6 & d & 61 \\
& $\begin{array}{l}\text { sity } \rightarrow \\
\text { WTP }\end{array}$ & 05 & 79 & $.219)$ & 36 & 1 & rted & 76 \\
\hline
\end{tabular}

Table 5 shows the results of the $\mathrm{R}^{2}, \mathrm{Q}^{2}$ and the $\mathrm{f}^{2}$ of the study. $\mathrm{R}^{2}$ indicating the variance on the endogenous variable explained by exogenous variables of the study. As general guidelines provided by (Hair et al., 2017), $\mathrm{R}^{2}$ value of $0.75,0.5$ and 0.25 can be considered as substantial, moderate and weak, hence with the $\mathrm{R}^{2}$ of $29.2 \%$, it can considered that exogenous of the study only capable to explain $29.2 \%$ from the overall variance of willingness to pay for Halal transportation cost. To analyze the predictive accuracy, to study used the $Q^{2}$ by (Geisser, 1974). The study found that the $\mathrm{Q}^{2}$ is 0.234 which is higher than 0 , as mentioned by Hair et al., (2013), thus, the study can claim that the model has a predictive accuracy of the structural model for that construct. Lastly, to ensure which variable is more important in explaining the endogenous variable, effect size $\left(f^{2}\right)$ analysis was applied. (Cohen, 1988) set the rule of thumb of 0.02, 0.15 and 0.35 as small, medium and large effect size. The study found that attitude and perceived behavioral control have a small effect size in their relationship with the willingness to pay for Halal transportation cost.

TABle 5: CoefFicient of Determination (R2), And EFFeCT SizE (F2)

\begin{tabular}{lllll} 
Construct & $\mathrm{R}^{2}$ & $\mathrm{Q}^{2}$ & $f^{2}$ & Decision \\
\hline WTP & 0.292 & 0.234 & & \\
Att & & & 0.071 & Small \\
Pbc & & & 0.037 & Small \\
\hline
\end{tabular}

As proposed by (Hair, Risher, Sarstedt, \& Ringle, 2018), proposed to test the predictive power using (Shmueli, Ray, Velasquez Estrada, \& Chatla, 2016). The model assumed to have less error in predicting performance if the RMSE, MAE and MAPE values in the PLS model has lower values compared to the Linear model (LM), and the Q2 value for PLS is higher than LM (Shmueli et al., 2016). As shown in Table 6, all values fulfill the requirements, hence it indicates that the theoretically establish a path model improves the predictive performance of the available indicator data.

TABLE 6: PREDICTIVE ACCURACY

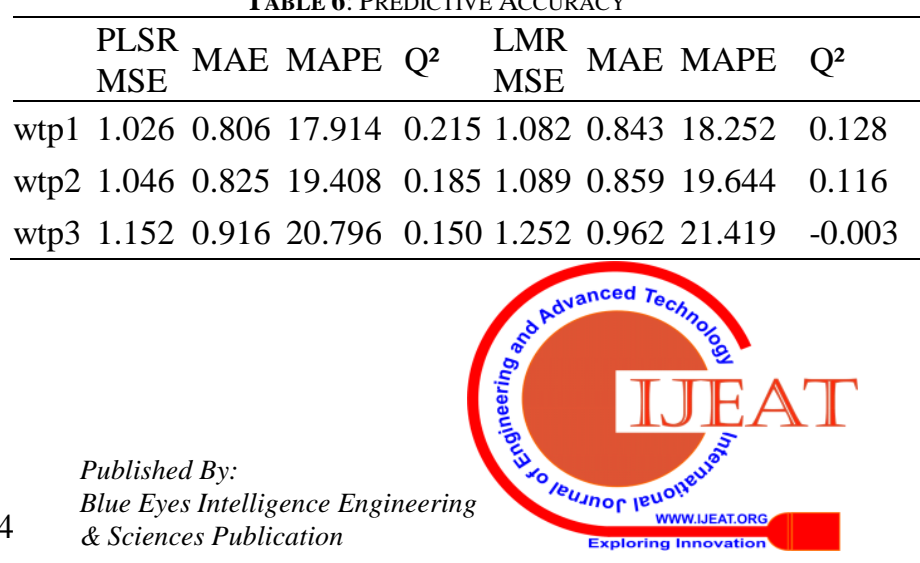


Table 7 illustrates the moderating effect of knowledge towards variables representing the theory of planned behavior. The result reveals that knowledge only moderates the relationship between attitude and willingness to pay for the Halal transportation cost. Figure 2, is Dawson's plot elucidates the moderation effect of knowledge on the supported hypothesis. As pictured in the image, the line labeled high knowledge has a steeper gradient as compared to low knowledge. This exemplifies that the relationship between attitude and willingness to pay for Halal transportation is stronger when the knowledge is high, H5 was confirmed.

TABLE 7: MODERATING EFFECT OF KNOWLEDGE

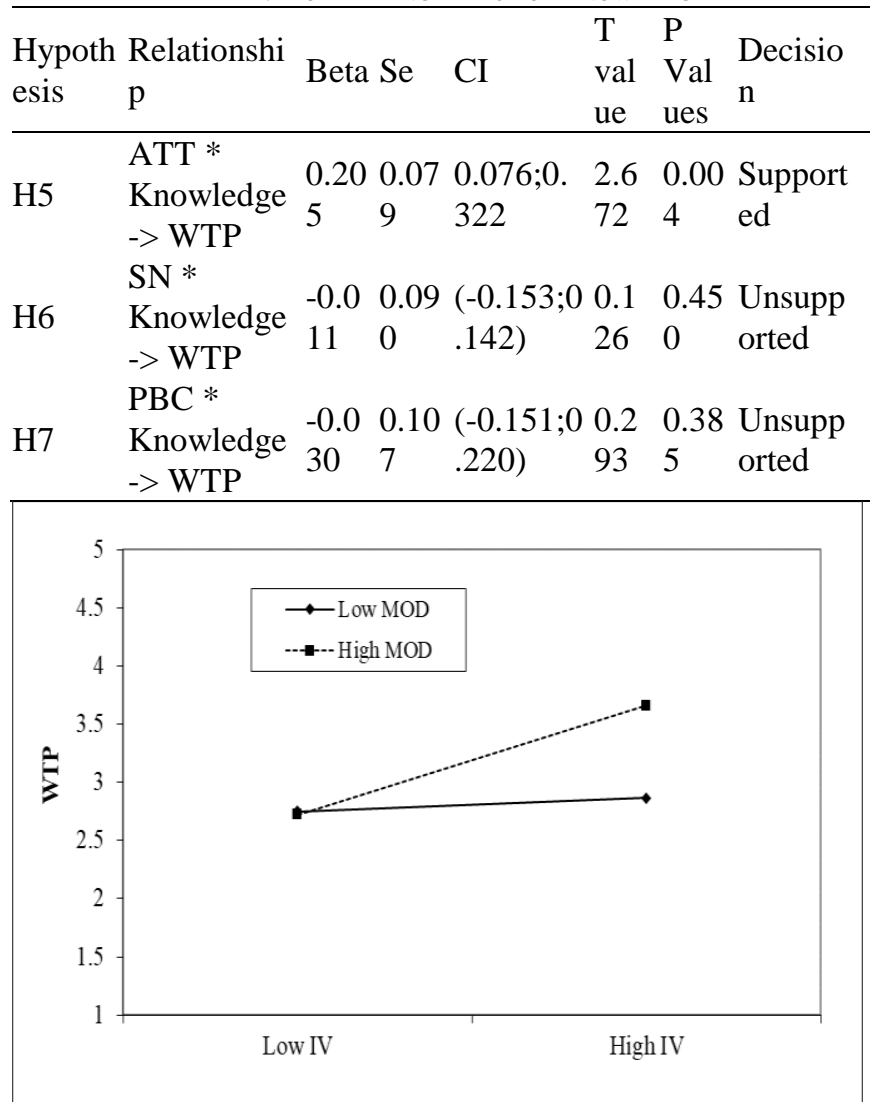

Fig 2: Moderation effect of knowledge

\section{DISCUSSION AND CONCLUSION}

The study revealed that, from three hypotheses for the Theory of Planned behavioral, only two hypotheses were supported. $\mathrm{H} 1$ and $\mathrm{H} 3$ which represent the attitude and perceived behavioral control were found to have a positive relationship with the willingness to pay for the Halal transportation cost. The findings were confirming past studies by Spash et al., (2009); López-Mosquera \& Sánchez, (2012); Yadav \& Pathak, (2017); and Sánchez et al., (2018) for attitude, and Spash et al., (2009); López-Mosquera \& Sánchez, (2012); Yadav \& Pathak, (2017) for perceived behavioral control. This indicates that the relevant parties regarding the willingness to pay for Halal transportation should focus on these two variables if they would like to enhance the willingness to pay for the Halal transportation cost. Meanwhile, for subjective norms, the study found it was unsupported. This finding consonant with the findings by (Meleddu \& Pulina, 2016) and Sánchez et al., (2018) in their study on tourism and environmental study, respectively. This result shows that, in the case of willingness to pay for the Halal transportation cost, people's who are important to respondents were not influencing their willingness to pay for the Halal transportation cost. This study also makes sense within the actual practice, where the decision either to pay or not to pay, is not about what others' thinking, since the impacts of the behavior will not reflect on the person who is important to them, but the respondents themselves. Hence, $\mathrm{H} 2$ was unsupported.

Even literature claimed that religiosity has a positive relationship with the Halal matters since it was closely tied with the Islamic values, interestingly, this finding of the study contradicts to the literature. On top of that, this finding is aligned with the Hasan Bukhari et al., (2019) when he mentioned that religiosity has no relation to the buying behavior especially on the food products. In another study, Meng, McLaughlin, Pariera, \& Murphy, (2016) also found that religiosity also not a significant factor towards a willingness to join a cancer test. Hence the study reveals that religiosity does not relate to the willingness to pay for the Halal transportation cost. The respondents believe, it is not their responsibility to pay for the Halal transportation cost, merely for the producers who claimed that their products were Halal certified. Once the products were stamped with Halal, the obligation to preserve the Halal quality is also on their shoulders.

The study also found that knowledge moderated the relationship between attitude and willingness to pay. It shows that higher the knowledge which leads to a better understanding of their religious obligation to commit to purely Halal products in whatever cost they should spend. On top of that, knowledge does not have a moderation effect between subjective norms and perceived behavioral control towards the willingness to pay for the Halal transportation cost. It establishes that knowledge does not have an impact on subjective norms and perceived behavioral control. It may due to the belief that, once the products have Halal stamp, it is already Halal to be consumed. All the transportation cost has been hidden by the producers, and they did endure the cost directly when they buy the merchandise.

\section{A. Conclusion}

The study indicates that attitude and perceived behavioral control has a positive relationship with the willingness to pay for Halal transportation. Hence, the manager for Halal manufacturers and Halal transportation providers should concern on these factors if they want to increase the willingness to pay for Halal transportation. Commonly were understand the importance of this service to preserve the Halal quality. However, if this service can't sustain, it will only give a negative impact to the providers, but also for a Muslim consumer who is looking for the pure quality of Halal products to be consumed. Hopefully, this finding will be helpful for relevant parties to begin coordinating the session or talks to increase the positive position towards this subject. On the other hand, it is required that managers could come away with a fresh scheme to enhance the willingness to pay for the Halal transportation cost among Muslim consumers 
especially, and also for non-Muslim consumers.

\section{B. Recommendation for future studies}

The study demonstrates the capability of the theory of planned behavior and religiosity to explain the willingness to pay for the Halal transportation cost for Muslim consumers in Malaysia. Since Halal is not exclusively for Muslim consumers but commenced to be looked for by the non-Muslims, future study show looks at the non-Muslims as the respondents of the survey. It is more meaningful if the survey is conducted by the non-Muslim lands, but having quite a number of the Muslim population in the rural areas. This sort of study would reveal a bigger impact on the halal studies since Halal is not part of their religious duty

\section{REFERENCE}

[1] Abd Rahman, A., Asrarhaghighi, E., \& Ab Rahman, S. (2015). Consumers and halal cosmetic products: Knowledge, religiosity, attitude and intention. Journal of Islamic Marketing, 6(1), 148-163. https://doi.org/10.1108/JIMA-09-2013-0068

[2] Abid Haleem, D., Mohd Imran Khan, M., Shahbaz Khan, M., Abdul Hafaz Ngah, D., Haleem, A., Imran Khan, M., ... Hafaz Ngah, A. (2018). Assessing Barriers to Adopting and Implementing Halal Practices in Logistics Operations. IOP Conference Series: Materials Science and Engineering, 404(1). https://doi.org/10.1088/1757-899X/404/1/012012

[3] Aguinis, H., Boik, R. J., \& Pierce, C. A. (2001). A Generalized Solution for Approximating the Power to Detect Effects of Categorical Moderator Variables Using Multiple Regression. In Organizational Research Methods (Vol. 4).

[4] Ahmat, N.C., Radzi, S.M., Zahari, M.S.M., Muhammad, R., aziz, A.A and Ahmad, N. A. (2011). The effect of factors influencing the perception of prices fairness towards customer response behaviours. Journal of Global Management.

[5] Ahmed, W., Najmi, A., Faizan, H. M., \& Ahmed, S. (2018). Consumer behaviour towards willingness to pay for Halal products: An assessment of demand for Halal certification in a Muslim country. British Food Journal. https://doi.org/10.1108/BFJ-02-2018-0085

[6] Ajzen, I. (1991). The theory of planned behavior. Organizational Behavior and Human Decision Processes. https://doi.org/10.1016/0749-5978(91)90020-T

[7] Alam, S. S., Mohd, R., \& Hisham, B. (2011). Is religiosity an important determinant on Muslim consumer behaviour in Malaysia? Journal of Islamic Marketing, 2(1), 83-96. https://doi.org/10.1108/17590831111115268

[8] Ali, F., Rasoolimanesh, S. M., Sarstedt, M., Ringle, C. M., \& Ryu, K. (2018). An assessment of the use of partial least squares structural equation modeling (PLS-SEM) in hospitality research. International Journal of Contemporary Hospitality Management, 30(1), 514-538. https://doi.org/10.1108/IJCHM-10-2016-0568

[9] Ali, M. H., Tan, K. H., Makhbul, Z. M., \& Hafaz, N. A. (2016). Augmenting Halal Food Integrity through Supply Chain Integration (Menambahbaik Integriti Makanan Melalui Integrasi Rantaian Bekalan). Jurnal Pengurusan, 48, 17.

[10] Amin, H. (2016). Journal of Internet Banking and Commerce (http://www.icommercecentral.com/) Willingness to Open Islamic Gold Investment Accounts. Retrieved from http://www.icommercecentral.com/

[11] Babin, B. J., Griffin, M., \& Hair, J. F. (2016). Heresies and sacred cows in scholarly marketing publications. Journal of Business Research. https://doi.org/10.1016/j.jbusres.2015.12.001

[12] Bahrudin, S. S. M., Illyas, M. I., \& Desa, M. I. (2011). Tracking and tracing technology for halal product integrity over the supply chain. Proceedings of the 2011 International Conference on Electrical Engineering and Informatics, ICEEI 2011. https://doi.org/10.1109/ICEEI.2011.6021678

[13] Baron, R. M., \& Kenny, D. A. (1986). The Moderator-Mediator Variable Distinction in Social Psychological Research: Conceptual, Strategic, and Statistical Considerations. In Journal of Personality and Social Psychology (Vol. 51). meat production and the control and delivery of halal credence quality.
[14] Bonne, K., \& Verbeke, W. (2008). Religious values informing halal

Agriculture and Human Values, 25(1), 35-47. https://doi.org/10.1007/s10460-007-9076-y

[15] Choi, G., \& Parsa, H. G. (2007). Green Practices II. Journal of Foodservice Business Research, 9(4), 41-63. https://doi.org/10.1300/j369v09n04_04

[16] Choi, Y. (2010). Religion, religiosity, and South Korean consumer switching behaviors. Journal of Consumer Behaviour, 9(3), 157-171. https://doi.org/10.1002/cb.292

[17] Cohen, J. (1988). Statistical power for the social sciences. Hillsdale, NJ: Laurence Erlbaum and Associates.

[18] Cohen, J. (1992). Title: A Power Primer A Power Primer. In Psychological Bulletin (Vol. 112).

[19] Diamantopoulos, A., \& Siguaw, J. A. (2006). Formative versus reflective indicators in organizational measure development: A comparison and empirical illustration. British Journal of Management, $17(4), \quad 263-282$. https://doi.org/10.1111/j.1467-8551.2006.00500.x

[20] Fathi, E., Zailani, S., Iranmanesh, M., \& Kanapathy, K. (2016). Drivers of consumers' willingness to pay for halal logistics. British Food Journal, 118(2), 464-479. https://doi.org/10.1108/BFJ-06-2015-0212

[21] Franke, G., \& Sarstedt, M. (2018). Heuristics versus statistics in discriminant validity testing: a comparison of four procedures. Internet Research. https://doi.org/10.1108/IntR-12-2017-0515

[22] Geisser, S. (1974). A predictive approach to the random effect model. Biometrika. https://doi.org/10.1093/biomet/61.1.101

[23] Gholami, R., Sulaiman, A. B., Ramayah, T., \& Molla, A. (2013). Senior managers' perception on green information systems (IS) adoption and environmental performance: Results from a field survey. Information and Management. https://doi.org/10.1016/j.im.2013.01.004

[24] Green, S. B. (1991). How Many Subjects Does It Take To Do A Regression Analysis? Multivariate Behavioral Research, 26(3), 499-510. https://doi.org/10.1207/s15327906mbr2603_7

[25] Hafaz, N. A., Rahimi, A. H. M., \& Norzalita, A. A. (2018). The influence of electronic word of mouth on theory of reasoned action and the visit intention to the world monument fund site. Indian Journal of Public Health Research \& Development, 9(11), 1277-1282.

[26] Hafaz, N. A., \& Thurasamy, R. (2018). Modelling the Intention to Adopt Halal Transportation Among Halal Pharmaceutical and Cosmetic Manufacturers in Malaysia. Advanced Science Letters, 24(1), 205-207. https://doi.org/10.1166/asl.2018.11960

[27] Hafaz, N. A., Zainuddin, Y., \& Thurasamy, R. (2014a). Adoption of Halal Supply Chain among Malaysian Halal Manufacturers: An Exploratory Study. Procedia - Social and Behavioral Sciences, 129, 388-395. https://doi.org/10.1016/j.sbspro.2014.03.692

[28] Hafaz, N. A., Zainuddin, Y., \& Thurasamy, R. (2014b). Barriers and enablers in adopting Halal transportation services: A study of Malaysian Halal Manufacturers. International Journal of Business and Management, 2(2), 49-70. https://doi.org/10.1108/JIMA-03-2014-0027

[29] Hafaz, N. A., Zainuddin, Y., \& Thurasamy, R. (2014c). Contributing factors of Halal warehouse adoption. Management and Technology in Knowledge, Service, Tourism \& Hospitality, 89-94.

[30] Hafaz, N. A., Zainuddin, Y., \& Thurasamy, R. (2015). Barriers and enablers in adopting of Halal warehousing. Journal of Islamic Marketing, 6(3), 354-376. https://doi.org/10.1108/JIMA-03-2014-0027

[31] Hafaz, N. A., Zainuddin, Y., \& Thurasamy, R. (2017). Applying the TOE framework in the Halal warehouse adoption study. Journal of Islamic Accounting and Business Research, 8(2), 161-181. https://doi.org/10.1108/JIABR-04-2014-0014

[32] Hafiz Zulfakar, M., Jie, F., \& Chan, C. (2011). HALAL FOOD SUPPLY CHAIN INTEGRITY: FROM A LITERATURE REVIEW TO A CONCEPTUAL FRAMEWORK. Retrieved from https://www.researchgate.net/publication/275964284

[33] Hair, J., Hollingsworth, C. L., Randolph, A. B., \& Chong, A. Y. L. (2017). An updated and expanded assessment of PLS-SEM in information systems research. Industrial Management and Data Systems, $117(3), \quad 442-458$. https://doi.org/10.1108/IMDS-04-2016-0130

[34] Hair, Joe F, Risher, J. J., Sarstedt, M., \& Ringle, C. M. (2018). When to use and how to report the results of PLS-SEM. European Business Review, 00-00. https://doi.org/10.1108/ebr-11-2018-0203 
[35] Hair, Joseph F., Ringle, C. M., \& Sarstedt, M. (2013). Partial Least Squares Structural Equation Modeling: Rigorous Applications, Better Results and Higher Acceptance. Long Range Planning, 46(1-2), 1-12. https://doi.org/10.1016/j.lrp.2013.01.001

[36] Hair, Joseph F., Sarstedt, M., \& Ringle, C. M. (2019). Rethinking some of the rethinking of partial least squares. European Journal of Marketing, https://doi.org/10.1108/EJM-10-2018-0665

[37] Hair Jr., J. F., Matthews, L. M., Matthews, R. L., \& Sarstedt, M. (2017). PLS-SEM or CB-SEM: updated guidelines on which method to use. International Journal of Multivariate Data Analysis, 1(2), 107. https://doi.org/10.1504/ijmda.2017.10008574

[38] Hasan Bukhari, S. F., Woodside, F. M., Hassan, R., Shaikh, A. L., Hussain, H., \& Mazhar, W. (2019). Is religiosity an important consideration in Muslim consumer behavior: Exploratory study in the context of western imported food in Pakistan. Journal of Islamic Marketing. https://doi.org/ddoi.org/10.1108/JIMA-01-2018-0006

[39] Henseler, J., Ringle, C. M., \& Sarstedt, M. (2014). A new criterion for assessing discriminant validity in variance-based structural equation modeling. Journal of the Academy of Marketing Science, 43(1), 115-135. https://doi.org/10.1007/s11747-014-0403-8

[40] Jedidi, K., \& Zhang, Z. J. (2003). Augmenting Conjoint Analysis to Estimate Consumer Reservation Price. Management Science, 48(10), 1350-1368. https://doi.org/10.1287/mnsc.48.10.1350.272

[41] Kamaruddin, R., Iberahim, H., \& Shabudin, A. (2012). Willingness to Pay for Halal Logistics: The Lifestyle Choice. Procedia - Social and $\begin{array}{llll}\text { Behavioral Sciences, } & 50, & \text { 722-729. }\end{array}$ https://doi.org/10.1016/j.sbspro.2012.08.075

[42] Kamaruddin, R., Iberahim, H., \& Shabudin, A. (2018). Factors Influencing Customers Willingness to Pay for Halal Logistics. Journal of ASIAN Behavioural Studies, 3(6), 83. https://doi.org/10.21834/jabs.v3i6.240

[43] Khan, M., Najmi, A., Ahmed, W., \& Aman, A. (2019). The role of consumer willingness to pay for halal certification in Pakistan. Journal of Islamic Marketing, JIMA-09-2018-0155. https://doi.org/10.1108/JIMA-09-2018-0155

[44] Kim, E. A., \& Choi, S. E. (2016). Structural Equation Modeling on Living and Brain Death Organ Donation Intention in Nursing Students. Journal of Korean Academy of Nursing, 45(6), 802. https://doi.org/10.4040/jkan.2015.45.6.802

[45] Kline, R. B. (2011). Principles and Practice of Structural Equation Modeling. In Analysis. https://doi.org/10.1038/156278a0

[46] Kotler, P., \& Zeithaml, V. (2000). Marketing Management, Millenium Edition. Marketing Management. https://doi.org/10.1016/0024-6301(90)90145-T

[47] Lada, S., Harvey Tanakinjal, G., \& Amin, H. (2009). Predicting intention to choose halal products using theory of reasoned action. International Journal of Islamic and Middle Eastern Finance and Management, 2(1), 66-76. https://doi.org/10.1108/17538390910946276

[48] López-Mosquera, N., García, T., \& Barrena, R. (2014). An extension of the Theory of Planned Behavior to predict willingness to pay for the conservation of an urban park. Journal of Environmental Management, 135 , https://doi.org/10.1016/j.jenvman.2014.01.019

[49] López-Mosquera, N., \& Sánchez, M. (2012). Theory of Planned Behavior and the Value-Belief-Norm Theory explaining willingness to pay for a suburban park. Journal of Environmental Management, 113, 251-262. https://doi.org/10.1016/j.jenvman.2012.08.029

[50] Manaktola, K., \& Jauhari, V. (2007). Exploring consumer attitude and behaviour towards green practices in the lodging industry in India. International Journal of Contemporary Hospitality Management, 19(5), 364-377. https://doi.org/10.1108/09596110710757534

[51] Meleddu, M., \& Pulina, M. (2016). Evaluation of individuals' intention to pay a premium price for ecotourism: An exploratory study. Journal of Behavioral and Experimental Economics, 65, 67-78. https://doi.org/10.1016/j.socec.2016.08.006

[52] Meng, J., McLaughlin, M., Pariera, K., \& Murphy, S. (2016). A Comparison Between Caucasians and African Americans in Willingness to Participate in Cancer Clinical Trials: The Roles of Knowledge, Distrust, Information Sources, and Religiosity. Journal of Health Communication, 21(6), https://doi.org/10.1080/10810730.2016.1153760

[53] Omar, E. N., \& Jaafar, H. S. (2011). Halal supply chain in the food industry - A conceptual model. ISBEIA 2011 - 2011 IEEE Symposium on Business, Engineering and Industrial Applications, 384-389. https://doi.org/10.1109/ISBEIA.2011.6088842
[54] Pettinger, C., Holdsworth, M., \& Gerber, M. (2004). Psycho-socia influences on food choice in Southern France and Central England. Appetite, 42(3), 307-316. https://doi.org/10.1016/j.appet.2004.01.004

[55] Podsakoff, P. M., MacKenzie, S. B., Lee, J. Y., \& Podsakoff, N. P. (2003, October). Common Method Biases in Behavioral Research: A Critical Review of the Literature and Recommended Remedies. Journal of Applied Psychology, Vol. 88, pp. 879-903. https://doi.org/10.1037/0021-9010.88.5.879

[56] Podsakoff, P. M., MacKenzie, S. B., \& Podsakoff, N. (2012). Sources of Method Bias in Social Science Research and Recommendations on How to Control it. In SSRN https://doi.org/10.1146/annurev-psych-120710-100452

[57] Ringle, C. M., Wende, S., \& Becker, J. M. (2015). "Smart PLS 3." Boenningstedt: SmartPLS GmbH. Retrieved from http://www.smartpls.com

[58] Rivis, A., Sheeran, P., \& Armitage, C. J. (2006). Augmenting the theory of planned behaviour with the prototype/willingness model Predictive validity of actor versus abstainer prototypes for adolescents' health-protective and health-risk intentions. British Journal of Health Psychology, 11(3), https://doi.org/10.1348/135910705X70327

[59] Sánchez, M., López-Mosquera, N., Lera-López, F., \& Faulin, J. (2018). An Extended Planned Behavior Model to Explain the Willingness to Pay to Reduce Noise Pollution in Road Transportation. Journal of Cleaner Production, $177, \quad 144-154$. https://doi.org/10.1016/j.jclepro.2017.12.210

[60] Shmueli, G., Ray, S., Velasquez Estrada, J. M., \& Chatla, S. B. (2016) The elephant in the room: Predictive performance of PLS models. Journal of Business Research. https://doi.org/10.1016/j.jbusres.2016.03.049

[61] Spash, C. L., Urama, K., Burton, R., Kenyon, W., Shannon, P., \& Hill, G. (2009). Motives behind willingness to pay for improving biodiversity in a water ecosystem: Economics, ethics and social psychology. Ecological Economics, 68(4), 955-964 https://doi.org/10.1016/j.ecolecon.2006.09.013

[62] Syazwan, M., Talib, A., Rubin, L., \& Zhengyi, V. K. (n.d.). Qualitative Research on Critical Issues In Halal Logistics. Retrieved from www.jeeir.com

[63] Tieman, M. (2011). The application of Halal in supply chain management: In-depth interviews. Journal of Islamic Marketing. https://doi.org/10.1108/17590831111139893

[64] Tieman, M. (2013). Establishing The Principles In Halal Logistics. Journal of Emerging Economies an Islamic Research.

[65] Tieman, M., \& Ghazali, M. C. (2013). Principles in halal purchasing. Journal of Islamic Marketing. https://doi.org/10.1108/JIMA-01-2012-0004

[66] Tommasetti, A., Singer, P., Troisi, O., \& Maione, G. (2018). Extended Theory of Planned Behavior (ETPB): Investigating customers' perception of restaurants' sustainability by testing a structural equation $\begin{array}{llll}\text { model. } & \text { Sustainability } & \text { (Switzerland), }\end{array}$ https://doi.org/10.3390/su10072580

[67] Urbach, N., \& Ahlemann, F. (2010). Structural Equation Modeling in Information Systems Research Using Partial Least Squares (Vol. 11).

[68] Venkatesh, V., Brown, S., \& Hoehle, H. (2012). Understanding Technology Adoption in the Household Context: a Comparison of Seven. European Conference on Information Systems.

[69] Weaver, G. R., \& Agle, B. R. (2002). Religiosity and Ethical Behavior in Organizations: A Symbolic Interactionist Perspective. In Source: The Academy of Management Review (Vol. 27).

[70] Worthington, E. L., Wade, N. G., Hight, T. L., Ripley, J. S., McCullough, M. E., Berry, J. W., ... O'Connor, L. (2003). The Religious Commitment Inventory-10: Development, refinement, and validation of a brief scale for research and counseling. Journal of Counseling Psychology, 50(1), 84-96. https://doi.org/10.1037/0022-0167.50.1.84

[71] Yadav, R., \& Pathak, G. S. (2017). Determinants of Consumers' Green Purchase Behavior in a Developing Nation: Applying and Extending the Theory of Planned Behavior. Ecological Economics. https://doi.org/10.1016/j.ecolecon.2016.12.019 
Willingness to Pay for Halal Transportation Cost: The Moderating Effect of Knowledge on the Theory of Planned Behavior

\section{AUTHOR PROFILE}

I am Hafaz N.A, currently I am affiliated with Maritime Management, School of Business Maritime and Management, Universiti Malaysia Terengganu, Kuala Nerus, Terengganu, 21030, Malaysia. Terengganu, Kuala
hafaz.ngah@umt.edu.my

I am Jagan Jeevan, currently I am affiliated with Maritime Management, School of Business Maritime and Management, Universiti Malaysia Terengganu, Kuala Nerus, Terengganu, 21030, Malaysia

I am Nurul Haqimin Mohd Salleh, currently I am affiliated with Maritime Management, School of Business Maritime and Management, Universiti Malaysia Terengganu, Kuala Nerus, Terengganu, 21030, Malaysia

I am Taylor Tae Hwee Lee, currently I am affiliated with Department of Distribution, Gyeongnam National University of Science and Technology, Jinju, South Korea

I am Marsila Mhd Ruslan, currently I am affiliated with Maritime Management, School of Business Maritime and Management, Universiti Malaysia Terengganu, Kuala Nerus, Terengganu, 21030, Malaysia 